\title{
Biodiversity in agricultural and food systems of jhum landscape in the West Garo Hills, North-eastern India
}

\author{
Dileep Kumar Pandey ${ }^{1}\left[\right.$ (D) Kalkame Ch Momin ${ }^{1} \cdot$ Shantanu Kumar Dubey ${ }^{2} \cdot$ Poovaragavalu Adhiguru $^{3}$
}

Received: 30 April 2021 / Accepted: 21 December 2021 / Published online: 16 January 2022

(c) International Society for Plant Pathology and Springer Nature B.V. 2021

\begin{abstract}
Jhum is a swidden agriculture agroforestry system indigenous to India. It enriches crop diversity and dietary diversity, helping to ensure food security and nutrition. However, jhum is now being rapidly abandoned in favour of intensive agriculture, often involving monoculture. Such changes in land use are a major threat to local food security. Based on a survey of 97 households in four villages of the West Garo Hills in the state of Meghalaya in north-eastern India, jhum and the corresponding food diversity (as maintained by the Garo indigenous communities) were examined. We used a mixed-methods approach to quantify the contribution to dietary diversity, and food and nutritional security. The jhum system of farming comprised of 39 crops and four indigenous breeds of livestock, which were categorized into five core food groups that sustain nutritional security and the food culture of indigenous people. The traditional food basket is supplemented with wild edible plants collected from fringes of forest and jhum fallows that are part of the system. The traditional foods of Garo communities, that are drawn almost entirely from locally available sources, are a significant part of local culture, and serve to reinforce conservation of biodiversity. The traditional food diversity guarded by indigenous people can serve as a basis for designing and implementing public policies aimed at ensuring food security of those regions that practise such systems, and more widely. Given this close interdependence between agrobiodiversity, culture, and livelihoods prevailing in the community, the present study recommended for keeping some area under traditional land use, supplemented with fresh measures to ensure its economic viability.
\end{abstract}

Keyword Agrobiodiversity · Food security · Indigenous farming communities · Shifting cultivation · Jhum farming in north-eastern India

Dileep Kumar Pandey

dkpextension@gmail.com

Shantanu Kumar Dubey

skumar710@gmail.com

Poovaragavalu Adhiguru

p.adhiguru@gmail.com

1 College of Horticulture and Forestry, Central Agricultural University Manipur, Pasighat, 791102 Arunachal Pradesh, India

2 ICAR-Agricultural Technology Application Research Institute, Kanpur-208019, Uttar Pradesh, India

3 Agricultural Extension Division, Indian Council of Agricultural Research (ICAR) Headquarters, KrishiAnusandhanBhavan - I, PUSA, New Delhi-110012 New Delhi, India

\section{Introduction}

Local and regional agrobiodiversity, encompassing both cultivated and wild plants and animals, is well recognized as indispensable to the nutritional security and food sovereignty of many indigenous smallholder communities (Nemoga, 2019; Whyte, 2017). Agricultural biodiversity is a subset of that diversity, limited to plants, animals, and other organisms relevant to food and farming as well as to the network of relationships that secure these forms of life as species and in ecosystems. For a food system, agrobiodiversity provides a variety of nutrient-rich foods and dietary ingredients with significant health value that are locally accessible and also adds diversity to the food basket. Because agrobiodiversity is intertwined with the traditions, practices, and food culture of communities, it can reinforce socio-cultural factors governing a wide range of food choices by individuals that are essential for a healthy population (Fanzo et al., 2011). 
The agricultural biodiversity and dietary diversity relationship is often complex (Chappell \& LaValle, 2011; Jones, 2017). Several studies have shown how agrobiodiversity may potentially enhance nutrition by improving the quality of diets (Ickowitz et al., 2016; Kuhnlein et al., 2013). Consuming diverse foods across food groups and from different varieties of specific foods is generally recommended, because dietary diversity is a vital element of a quality diet (Herforth et al., 2019). Thus enhanced agricultural biodiversity dominated by nutrient-dense plants, crops or shrubs and some agroforestry trees, may add immense value for dietary diversity (Lourme-Ruiz et al., 2021).

Agrobiodiversity and sustainable food futures are mutually dependent (Zimmerer \& Haan, 2017) and influence human health and nutrition, and may help manage effects of climate change (Zimmerer et al., 2019). However, overall the global food system is extraordinarily low in diversity, thereby often impacting dietary quality. Three cereal crops (wheat, rice and maize) and sugar provide $50 \%$ of the total calories utilized by human beings (FAOSTAT, 2018; Poore \& Nemecek, 2018). These foods are energy-dense and nutrient-starved (Khoury et al. 2014). There is underconsumption of fruits and vegetables in almost all regions of the world (Berners-Lee et al., 2018).

Protecting and leveraging agrobiodiversity can ensure dietary diversity and food and nutritional security for indigenous communities, fostering sustainable diets and leading to overall well-being (Hunter and Fanzo 2013; Johns \& Sthapit, 2004; Padulosi et al., 2013). In developing countries, traditional smallholder farmers and pastoralists are the major contributors to food and nutrition security. Usually, locally produced crop and animal products are consumed within smallholder households which enhance the nutrient quality of local diets, providing culturally preferred foods, and ultimately ensuring healthy dietary patterns rooted in regional ecosystems, community practices and customs (Johns \& Eyzaguirre, 2006). Traditional and indigenous food systems have tremendous biological and cultural diversity which can be harnessed through traditional knowledge of nutrient-dense, agro-biodiverse foods to improve food and nutrition security (Vogliano et al., 2021).

North-eastern India is part of the Indo-Burma biodiversity hotspot (one of the biodiversity hotspots of the world) which covers 17.2 million ha of forests, accounting for about $25 \%$ of India's total forest area (FSI, 2019). This region is home to more than a hundred indigenous communities, who have traditionally practised forms of swidden or shifting cultivation (locally referred to as jhum farming), for centuries (Rathore et al., 2010). Such traditional agroforests are practised as an integrated approach to environmental conservation, which is now considered to be an improved sustainable system featuring significant ecological interaction between the woody and non-woody components (Deb, 2020). Jhum cultivation involves the simultaneous cultivation of 15-20 mixed crops in the same field to fulfil household needs (Giri et al., 2020). Under such traditional agricultural systems, farmers retain 'folk-varieties' or 'landraces', 'farmers' varieties', 'local varieties' or 'traditional varieties' which have been repeatedly selected and preserved by farmers for many years (Das \& Das, 2020). Many of these wild and locally cultivated edible plants and fruits are significant in the life and traditional culture of the indigenous peoples of Northeast India (Pachuau \& Dutta, 2020). Value added products like fermented bamboo shoot-based food products are prepared by local people, which can be used as functional foods as they are rich in probiotics (Behera \& Balaji, 2021). Besides health benefits, these fermented products have industrial and economical value, a few of which are readily available in the local market.

Despite the importance of local foods to local people and their diets, such foods are never the focus of large-scale hunger eradication or nutrition promotion or livelihood improvement programs (Materia et al., 2021). Just a few studies are available which emphasize sustaining indigenous cultural food practices and cross-cultural sharing of such food practices by various racial, cultural, and ethnic groups within multicultural societies (Reddy \& van Dam, 2020). There is little nationally or regionally representative data to examine indigenous peoples' local food systems, utilization of agrobiodiversity, diet quality, and food security. Yet, empirical data from these areas should be very worthwhile to help improve policies, programmes, and educational interventions aimed at achieving zero hunger through the promotion of sustainable food systems (Vogliano et al., 2021).

The future potential of these indigenous food systems in the region must also be seen in the context of transitions in land use. These include a rapid shift to plantation food and non-food crops like cashew nut, black pepper, tea, areca nut, rubber, broom grass (Thysanolaena maxima) etc., as driven by state policies. For example, in the year 2000, jhum spread over $1328 \mathrm{~km}^{2}$ in the West Garo Hills district of north-eastern India, but by 2015 the area was down to only $112 \mathrm{~km}^{2}$. During the same period, the area under plantation crops (mainly betel nut, cashew, and tea) increased significantly (by $277 \mathrm{~km}^{2}$ ), and that under betel nut and citrus doubled. Rubber plantations were not seen in the district earlier but had spread over more than $70 \mathrm{~km}^{2}$ by 2015 (GoM, 2019; NRSC, 2019). Such rapid large-scale changes in land use have a strong bearing on declines in the agrobiodiversity and supported ecosystem services in the region, with both long- and short-term implications for food security (Behera et al., 2016).

With this background, in the present study we attempted to quantify the agrobiodiversity and corresponding ethnofood diversity of the indigenous jhum agroforestry system practised in the West Garo Hills of north-eastern India. 


\section{Methods}

\subsection{Study area}

The study was carried out in West Garo Hills district $\left(25^{\circ} 34^{\prime} 4.57^{\prime \prime} \mathrm{N}, 90^{\circ} 13^{\prime} 28.08^{\prime \prime} \mathrm{E}\right)$, which forms part of the western boundary of the state of Meghalaya, India. It is flanked by East Garo Hills district to the east, South Garo Hills to the south-east, Goalpara district of Assam to the north and north-west, and Bangladesh to the south (Fig. 1). This remote district has a moderate population density of 175 persons per square kilometre (GoI, 2011). The state has no written records of land ownership, and forests occupy nearly 78\% of West Garo Hills (FSI, 2019). The district is predominantly inhabited by Garos, the second largest tribe in Meghalaya, who are part of the Tibeto-Burman lineage that drifted into Eastern India and Myanmar across the plateau of Tibet. The Garos follow a matrilineal system -one of the few remaining matrilineal societies in the world- marked by matrilineal inheritance, family structure, and succession (GoM, 2021).

The jhum farming system is an ancient and popular system among the Garo indigenous communities, dominated by agro-silvi-pastoralism. Crops and livestock are the primary components of this system. Its features include crops on some parts of the landscape, along with pockets of land kept fallow for different durations, secondary forests on some fallow lands, and the original vegetation on other lands (Jeeva et al., 2006; Kurien et al., 2019). A small patch of the rainforest is cleared by cutting and burning of trees (slash-and-burn farming), leaving the larger trees intact because moving the heavy logs is difficult and because some of those trees produce edible fruit.

The Garo word for jhum is A.ba (Marak, 2018). In all villages in the Garo Hills, jhum is practised on community lands, which are controlled by the village chief, or the Nokma (Lahiri \& Das, 2010). Each Garo participant gets about a hectare (ha) of land, or a complete hillock, from the Nokma with the condition that the participant can neither sell that piece of land nor use it for anything other than farming (Nongkynrih, 2014; Sangma, 2012). In practice, the plot size allotted to each household varies from 0.2 ha to 1.25 ha depending upon the size of the household and the capacity of family labour. Land is typically prepared during February-March, and seeds are sown in April. Some traditional festivals are associated with jhum, including those involving praying for a good harvest, thanksgiving for a good harvest, welcoming the spring, and the 'wangala' harvest festival (Maaker, 2013).

\section{Data collection}

We randomly sampled 97 tribal households from four village clusters chosen from two purposively-selected community and rural development (C\&RD) blocks (a block is an administrative unit), namely Gambegre and Rongram (Fig. 1). The blocks were selected based on information provided by the district forest officer and by the head of the Krishi Vigyan Kendra (Farm Science Centre) of the district. The basis for selection was the extent or intensity of jhum and the highest density of households practising
Fig. 1 Four villages from two community and rural development blocks chosen for the study of jhum landscape biodiversity in the West Garo Hills district of northeast India

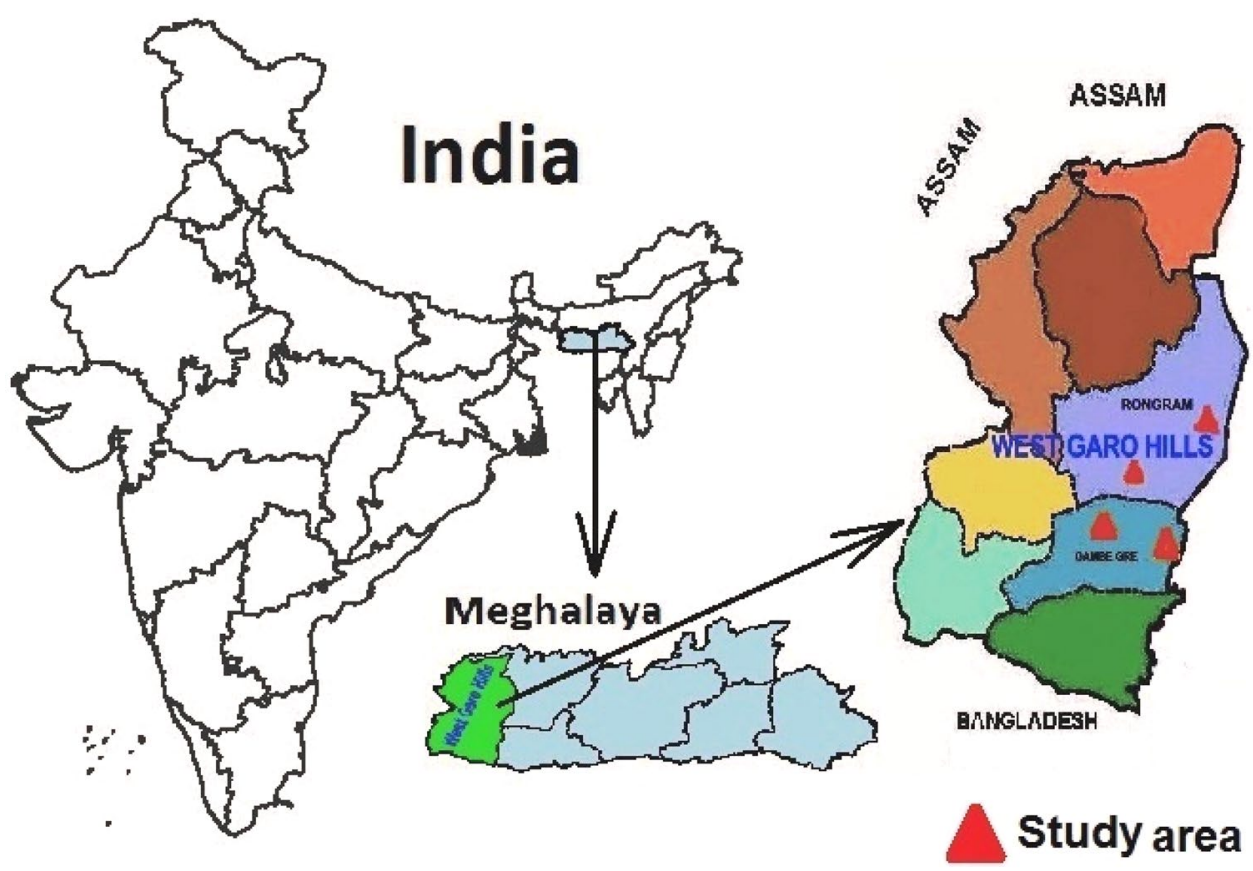


it. The villages for data collection were identified with the help of block-level officials taking into account accessibility for the survey. The four villages were Suringre and Dondagre from Gambegre block and Ganol Songma and Rombagre from Rongram block.

Agricultural biodiversity was measured by the variety of food crops grown, animals reared for food, and food items obtained from natural habitats by hunting, gathering, and trapping by household members. In developing countries, counting the different sources of food or food groups has been the most popular method of quantifying dietary diversity (Ruel, 2003). Thus, this method has been used in previous studies producing robust results. The survey schedule comprised four main sections, covering general information, land use and farming practices, crops (species and varieties) and livestock, and uses of wild edible plants. The schedule was designed according to the format suggested by the Platform for Agrobiodiversity Research (PAR, 2018) in the local language and consisted of simple questions that required only brief answers. To encourage bottom-up participation, voluntary, prior, and informed consent was taken from the respondents. Initially, each respondent was asked to recall all the possible crops and kinds of livestock to ensure that all the different types of crops (cereals, root and tuber crops, vegetables, fruits, oilseeds, legumes, and so on) and breeds of livestock were covered. In addition, the extent of preferences was also gathered on commonly consumed wild food plantsby eliciting the frequency of preference (i.e., those which were cited by more people). Species density was measured considering the household as a quadrate using the following formula as described by Dupuis and Goulard (2011), along with household-level assessment of agrobiodiversity (Guo et al., 2002).

Density $=\frac{\text { Total number of individuals of all species }}{\text { Number of quadrates per units studied }} \times 100$

To assess the nutritional security of households, the documented species and breeds were categorized into four core food groups as specified by the manual on dietary guidelines for Indians published by the National Institute of Nutrition (NIN, 2011). A fifth group, namely spices, was added given its high culinary and medicinal importance according to respondents. Further, we have calculated household dietary diversity score (HDDS) adopting FAO guidelines. The HDDS is operationalized as the indication of household economic access to food while, individual scores referred mainly the nutritional quality of the diet (Kennedy et al., 2010). The respondents, especially those engaged in food preparation in the households, were asked whether anyone in the household had consumed either of items from the food groups in the last
$24 \mathrm{~h}$. By summing all food groups included in the dietary diversity score, we have computed values for the dietary diversity variable.

Additionally, the diversity of ethnic and traditional foods prepared and consumed in various social events of the Garo people (which have gastro-cultural and socio-ecological importance) was captured by conducting a focus-group discussion (FGD) in each village (the FGD questions/prompts are attached as supplementary material). FGDs are increasingly used to elicit qualitative information on the sensory properties of foods and on how those properties relate to food acceptability (Murray \& Baxter, 2003). All four FGDs were carefully planned by the research team, ensuring that each group consisted of at least 10-12 participants, selected purposively, and that approximately $50 \%$ of them were women. Each focus group was constructed by purposive sampling of the participants involving both genders, as is widely recommended, because FGD relies on the ability and capacity of participants to provide relevant information (Morgan, 1988). Moreover, a mixed gender group improves the quality of discussion and its outcomes (Freitas et al., 1998). The sessions, each of 1-2 $\mathrm{h}$, were designed to obtain the maximum amount of relevant information on the product or attribute of interest. A local moderator was engaged to ensure balanced and informative representation of the views of all participants. We assured participants that they would remain anonymous and that results of the discussions would be used only for our study. The moderator asked each participant about the food products usually prepared and consumed in households in their respective villages and asked them to place the products in the appropriate category in the case of cultivated and wild plants and livestock species. The guidelines to document traditional food systems of indigenous peoples, particularly "free list record form for community traditional food"of Kuhnlein et al. (2006) were followed, with suitable adaptations.

\section{Results}

\subsection{Species diversity}

The study categorized the documented bio-resources emerging from jhum into five food groups - cereals and legumes, vegetables, fruits, spices, and meat - to examine species richness and density (Table 1).

Each of the five food groups was dominated by at least two species of crops or livestock (Table 1), which emphasizes the diversity inherent in traditional farming. This buffers the system against risks and enhances food and nutritional security by ensuring supply of food around the year. Furthermore, 26 landraces of four crop species enrich the food basket and also mitigate environmental stress. These 
Table 1 Species richness and density in the sampled villages in the Garo Hills, India, by food group list of the crops

\begin{tabular}{|c|c|c|c|}
\hline Food group/crops & Density (\%) & Food group/crops/livestock & Density (\%) \\
\hline \multicolumn{4}{|l|}{ 1. Cereals and legumes (Annual) } \\
\hline Maize (Zea mays L.) [5] & 97.9 & Taro (Colocasia esculenta) & 13.4 \\
\hline Rice (Oryza sativa L.) [9] & 96.9 & Mustard (Brassica juncea) & 13.4 \\
\hline Pigeonpea(Cajanus cajan) & 21.6 & Potato (Solanum tuberosum) & 10.3 \\
\hline Cowpea(Vigna unguiculata) & 20.6 & Cucumber (Cucumis sativus) & 9.3 \\
\hline Chickpea(Cicer arietinum) & 15.5 & Cowpea (Vigna unguiculata spp.) & 8.2 \\
\hline 2. Fruits (Tree crops) & & Tomato (Solanum lycopersicum) & 4.1 \\
\hline Banana (Musa spp.) & 67.0 & Carrot (Daucas carota) & 3.1 \\
\hline Jackfruit (Artocarpus heterophyllus) & 60.8 & $\begin{array}{l}\text { 4. Spices and plantation crops (Annual and } \\
\text { perennial) }\end{array}$ & \\
\hline Sweet orange (Citrus sinensis) & 32.0 & Ginger (Zingiber officinale) & 77.3 \\
\hline Pineapple (Ananus sativus) & 24.7 & Chili (Capsicum spp.) [5] & 76.3 \\
\hline Naval orange (Citrus limonium) & 24.7 & Betel nut (Areca catechu) & 55.7 \\
\hline Cashew nut (Anacardium occidentale) & 17.5 & Turmeric (Curcuma longa) & 41.2 \\
\hline 3. Vegetables and tubers (Annual) & & Welsh onion (Allium fistulosum L.) & 14.4 \\
\hline Pumpkin (Cucurbita moschata) [7] & 84.5 & Garlic (Allium sativum spp.) & 13.4 \\
\hline Waxguard (Benincasa hispida) & 58.8 & Spirit weed (Eryngium foetidum) & 11.3 \\
\hline Yam (Dioscorea spp.) & 35.0 & Coconut (Cocos nucifera) & 6.2 \\
\hline Cabbage (Brassica oleracea var. Capitata) & 21.6 & Tea plant (Camellia sinensis) & 3.1 \\
\hline Brinjal (Solanum melongena) & 20.6 & 5. Meat & \\
\hline Squash (Cucurbita maxima) & 18.6 & Chicken (Gallus gallus domesticus) & 91.7 \\
\hline Cassava (Manihot esculenta) & 17.5 & Cattle (Bos Taurus) & 50.5 \\
\hline \multirow[t]{2}{*}{ Lady's finger (Abelmoschus esculentus) } & 15.5 & Pig (Sus scrofa domesticus) & 46.4 \\
\hline & & Goat (Capra aegagrus hircus) & 19.6 \\
\hline
\end{tabular}

Numbers in square brackets indicate number of landraces of the crop

landraces have rich gene pool thus strengthening the biodiversity, and also have strong cultural ties because of their cultural, social and ritual values as learned during FGD. Thus, food traditions are connected to the.

cultivation of crop landraces as they are co-evolved mutually shaping each other. The wide variation in environmental factors including physiography, geology, soils, and climate in the West Garo Hills has also contributed to the rich biodiversity of the district.

\section{Wild edible plants}

In traditional food systems, foods sourced from the wild often constitute a major share of the types of food. In our case, 15 foods (as high as $90 \%$ of the total) were from the wild (see Table 1). Such foods are nutritionally rich and also culturally important (Kuhnlein, 2009, 2017). The extent and types of wild edible plants consumed by the surveyed households is presented in Fig. 2.

Fresh shoots of bamboo were the most commonly consumed food obtained from the wild. This evidently derives from its sufficient availability, accessible by about
95\% of households. Bamboo shoots are consumed either fresh when they are in season (May to October) or dried, fermented, or pickled for off-season consumption, thus ensuring a stable supply round the year. The most common edible species of bamboo in the study area are Dendrocalamus hamiltonii, Bambusa tulda, B. pallida, and D. giganteus. Fewer households (less than $20 \%$ in each village) reported consuming wild edible fruits and vegetables, mushrooms, and medicinal plants, probably because such foods were either in short supply or not easily accessible to those households. Apart from the wild foods shown in Fig. 2, the following species are also commonly consumed by the Garo people: as vegetables, Zanthoxylum rhetsa, Z. armatum, Solanum violaceum, Clerodendrum glandulosum, Lasia spinosa, Dillenia scabrella, Rumex acetosa, Musa flaviflora, Rhynchotechumellipticum, Polygonum chinense, Amaranthus dubius, Oroxylum indicum, and Momordica subangulata subsp. Renigera, and as fruits, Baccaurea ramiflora, Calamus erectus, Grewia nervosa, Elaeagnus conferta, Eugenia claviflora, Ficus auriculata, Flacourtiaindica, Terminalia bellerica, Haematocarpus validus, Musa flaviflora, Protium serratum, Elaeocarpus floribundus, and Spondias pinnata. 
Fig. 2 Consumption pattern of wild edible plants by the Garo households in West Garo Hills, state of Meghalaya in northeastern India

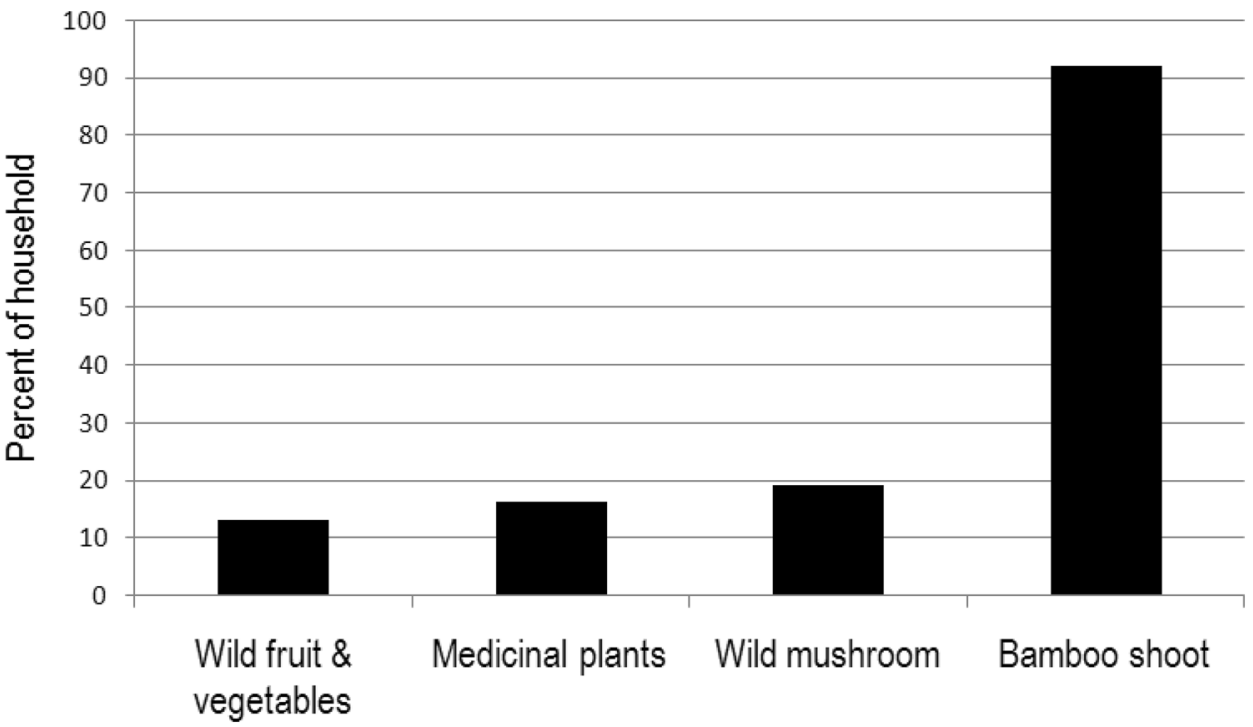

\section{Food diversity in the study area}

The active coupling of agrobiodiversity and consumption of local foods has been central to the Garo indigenous communities for several decades. Thus, the agrobiodiversity, the heterogeneous landscape, and the diversity of livelihoods all support the tribe's varied diet. Ethnic food products consumed in the study area are listed in Table 2.

As can be seen in Table 2, the Garos consume diverse (as many as 23) sources of food by exploiting the available biodiversity. The largest category was rice-based foods made from glutinous rice grains as the main substrate, which is grown in abundance on jhum lands. Most products were seasonal, particularly fruits and vegetables, whereas six were consumed occasionally. As revealed during FGDs, three major products from glutinous rice, namely menilpita, menilrita, and chubitchi (Fig. 3a, b, e), are prepared and consumed mainly during 'wangala', the most important festival, and also on other festive occasions such as 'rongchugala' (thanksgiving), 'do.si dodoka' (a traditional wedding), 'a.galmaka' (offerings after afield is cleared for jhum), and 'nokkingpina'(construction of new traditional home)(Fig. 4).

\section{Household dietary diversity}

The household dietary diversity score (HDDS) indicates the household's ability to access food in the last $24 \mathrm{~h}$, as well as its socioeconomic status (Kennedy et al., 2010). The dietary diversity score of the studied households is depicted in Table 3.

HDDS $=$ household dietary diversity score.

As evident from Table 3, the majority of households had average (score 4.41 to 7.23 ) levels of dietary diversity, about $23 \%$ showed low (score $<4.41$ ) dietary diversity, while about $7 \%$ of households had high levels of diet diversity. The mean HDDS was 5.82 (SD 1.41) out of twelve points. These results indicate that food system biodiversity in the jhum landscape has significantly contributed to dietary diversity since the majority of the households (77.3\%) fall into medium to high levels of HDDS. This necessitates the protection of forest lands and products from them, to continue to ensure the use of available rich food biodiversity thereby promoting the dietary diversity and ensuring better nutrition and health. However, a considerable percentage of households had a low ability to access food. There were indications from householders that this might be due to their poor socio-economic status including production diversity and lower female education status, especially primary education.

\section{Discussion}

Given the recent disruptions triggered by the COVID-19 pandemic, which have challenged health issues across the globe, the need to use agrobiodiversity as an instrument for resilience in informal food chains has been heightened (Zimmerer \& de Haan, 2020). Global transformations are driving a substantial decline of agrobiodiversity (Pilling et al., 2020). Yet it is clear that agrobiodiversity in foodgrowing spaces can enhance nutrition security and food sovereignty, may lessen vulnerability, and strengthen agroecological adaptive capacity and resilience (Pilling et al., 2020; Zimmerer et al., 2020). We provide ample evidence of this in our analysis of biodiversity in the agricultural and food systems of a changing jhum landscape of West Garo hills, in northeast India. Our work documented a wide array of agrobiodiversity in the study area which supported many 
Table 2 Documented ethnic food products consumed by the Garo indigenous communities in West Garo Hills, state of Meghalaya in northeastern India

\begin{tabular}{|c|c|c|c|}
\hline Local food or dish based on & Composition & Source (including wild edible plants) & Frequency of intake \\
\hline \multicolumn{4}{|l|}{ Rice } \\
\hline 1. 'Chira'(flour of sticky rice) & Minil (Sticky rice) & Oryza sativa & Occasional \\
\hline 2.'Rongchu'(beaten rice) & Local rice varieties & Oryza sativa & Seasonal \\
\hline 3.'Minil pita' & Minil (sticky rice), local rice, jaggery & Oryza sativa & Occasional \\
\hline 4. 'Minilrita'(steamed sticky rice) & $\begin{array}{l}\text { Minil (sticky rice), water, black } \\
\text { sesame (optional) }\end{array}$ & Oryza sativa, Sesamum indicum & Weekly \\
\hline 5. 'Chu bitchi'(rice beer) & $\begin{array}{l}\text { Minil (Sticky rice) ormisi (foxtail millet), } \\
\text { rice flour, red chillies, fern }\end{array}$ & $\begin{array}{l}\text { Minil (Oryza sativa), Setariaitalica, } \\
\text { Athyrium spp. }\end{array}$ & Festivals and occasions \\
\hline 6.'Jakkep' & $\begin{array}{l}\text { Minil (Sticky rice), water, black } \\
\text { sesame, jiggery }\end{array}$ & Oryza sativa, Sesasum indicum & Occasional \\
\hline \multicolumn{4}{|l|}{ Meat } \\
\hline 1.'Wak, Do.o', 'nat.tok'or 'brenga' & $\begin{array}{l}\text { Pork,chicken, or fish, kalchi (an } \\
\text { alkaline additive prepared from } \\
\text { banana pseudostem), green chillies } \\
\text { and ginger }\end{array}$ & Capsicum annum, Zingiber officinale & Occasionally \\
\hline 2.'Wak,Do.o' or 'matchupura' & $\begin{array}{l}\text { Pork, chicken, or beef, rice flour, } \\
\text { green chillies, ground ginger, kalchi, } \\
\text { green leafy vegetables }\end{array}$ & $\begin{array}{l}\text { Oryza sativa, Capsicum annum, } \\
\text { Zingiber officinale, Paederia foetida, } \\
\text { Clerodendrum glandulosum, Hibiscus } \\
\text { sabdariffa }\end{array}$ & Weekly \\
\hline $\begin{array}{l}\text { 3. 'Wak,Do.o,'matchu', or 'n.atok } \\
\text { kappa' }\end{array}$ & $\begin{array}{l}\text { Porkorchickenor beefor fish,green } \\
\text { chillies, and ginger cooked with } \\
\text { kalchi }\end{array}$ & Capsicum annum, Zingiber officinale & Weekly \\
\hline \multicolumn{4}{|l|}{ Bamboo } \\
\hline $\begin{array}{l}\text { 1.'Me.ameseng' } \\
\text { (fermented bamboo shoot) }\end{array}$ & Bamboo, water & Dendrocalamus hamiltonii & Weekly \\
\hline \multicolumn{4}{|l|}{ Cultivated and wild fruits } \\
\hline 1. 'Chambil gran’ & Fruits of Citrus macroptera & Citrus macroptera & Seasonal \\
\hline 2.'Sokmil gran’' & Fruits of Calamus erectus & Calamus erectus & Seasonal \\
\hline 3. 'Memangnarang gran' & Fruits of Citrus indica & Citrus indica & Occasional \\
\hline 4.Chirore' & Fruits of Terminalia bellerica & Terminalia bellerica & Seasonal \\
\hline 5. 'Angkil gran' and 'angkilginchi' & Whole fruit and endocarp of localber & Ziziphus mauritiana & Seasonal \\
\hline \multicolumn{4}{|l|}{ Cultivated and wild leaves } \\
\hline 1.'Me.jak gran' & Leaves of local mustard & Brassica juncea & Seasonal \\
\hline 2.'Alot gran' & Phlogacanthus thyrsiformis & Phlogacanthus thyrsiformis & Occasional \\
\hline 3. 'Gal.damikil gran' and 'gal.dagisi' & $\begin{array}{l}\text { Dried calyx and leaves of Hibiscus } \\
\text { safdariffa }\end{array}$ & Hibiscus safdariffa & Occasional \\
\hline 4. 'Do.dim'(fermented soyabean) & Soyabean and kalchi & $\begin{array}{l}\text { Glycine max, } \\
\text { Musa spp. }\end{array}$ & Weekly \\
\hline \multicolumn{4}{|l|}{ Fish } \\
\hline 1.'We.tepa' or O.sroma & $\begin{array}{l}\text { Freshwater fish orleafy vegetables, } \\
\text { kalchi, ginger, and chillies }\end{array}$ & $\begin{array}{l}\text { Amorphophallus paeoniifolius, Manihot } \\
\text { esculenta, Capsicum annum, Zingiber } \\
\text { officinale }\end{array}$ & Occasionally \\
\hline 2. 'Na'kambitchi' & $\begin{array}{l}\text { Fermented fish, kalchi, green chillies, } \\
\text { and ginger }\end{array}$ & Capsicum annum, Zingiber officinale & Daily \\
\hline $\begin{array}{l}\text { 3. 'Nakamsu.a' } \\
\text { (fermented fish) }\end{array}$ & $\begin{array}{l}\text { Local fish (na.ware, chenda, putti), } \\
\text { kalchi (alkaline additive) }\end{array}$ & Pseudostem of Musa spp. & Daily \\
\hline
\end{tabular}

ecosystem services, thereby serving the wellbeing of Garo indigenous people.

In the food group 'cereals and legumes', the preponderance of maize and rice provides food, animal feed, and nutritional security and also supports other diverse uses.
For example, maize was a key ingredient of animal feed, while rice is a staple consumed three times a day by Garos, in many traditional forms including white rice ('migra'), red rice ('mi gitchak'), black rice ('mi Gisim'), and sticky rice ('minil'). Glutinous or sticky rice (Oryza sativa cv. 
Fig. 3 Documented wild edible plants in the study area $\mathbf{a}$ and $\mathbf{b}$. Dendrocalamus hamiltonii; $\mathbf{c}$.

Houttuynia cordata; d. Hibiscus sabdariffa; e. Solanum violaceum; f. tender leaves and stems of Amorphophallus paeoniifolius; g. Diplazium esculentum; h. Citrus indica ('me.mang' or 'narang'); i. Calamus erectus ('sokmil'); j. Citrus macroptera (chambil); k. Ziziphus mauritiana; l. Elaeagnus conferta: m. Baccaurea ramiflora; $\mathbf{n}$. Phlogacanthus thyrsiformis; $\mathbf{o .}$ Zanthoxylum rhetsa; p. Tricholoma sp. (a wild edible macro fungus)
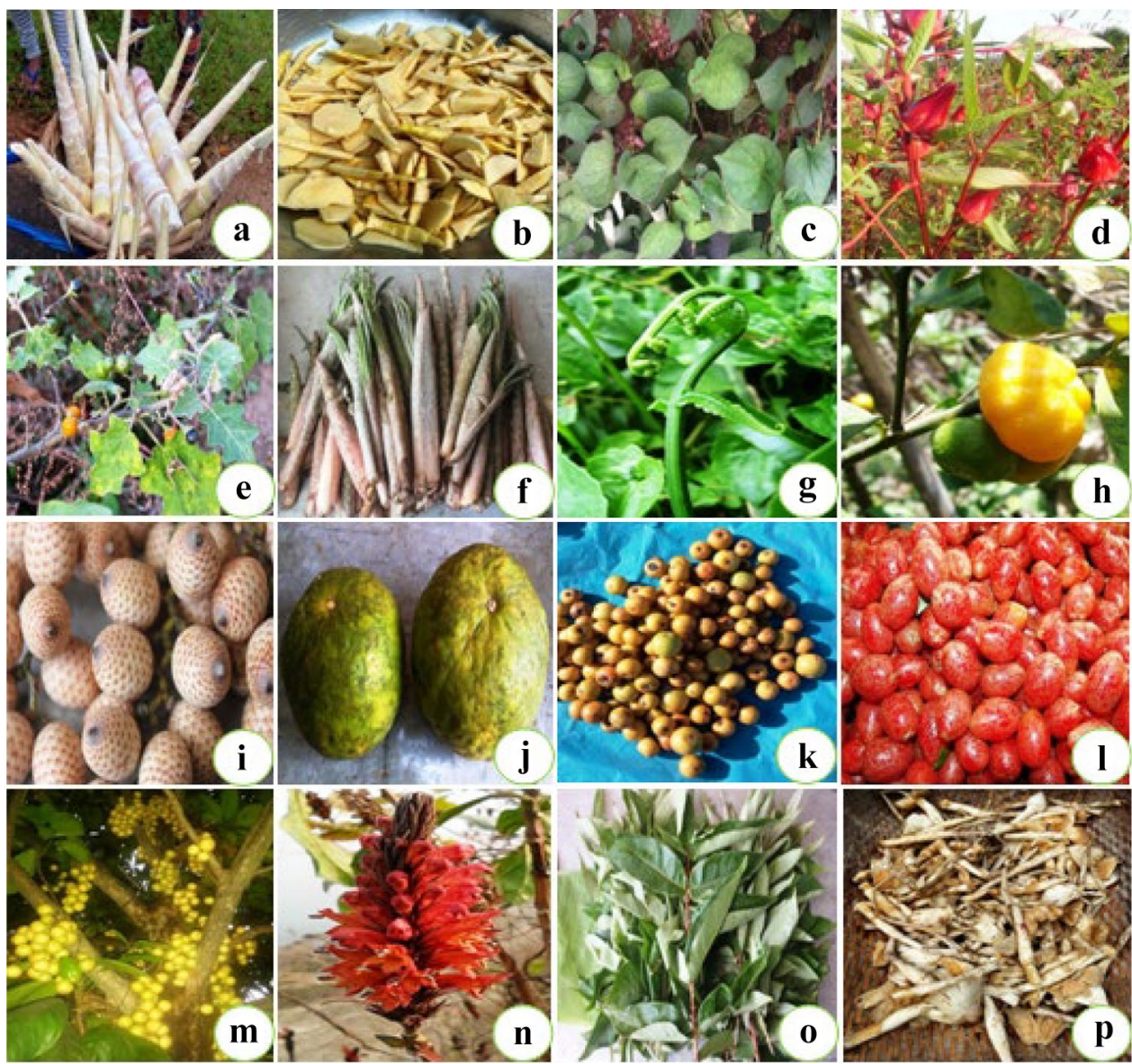

k

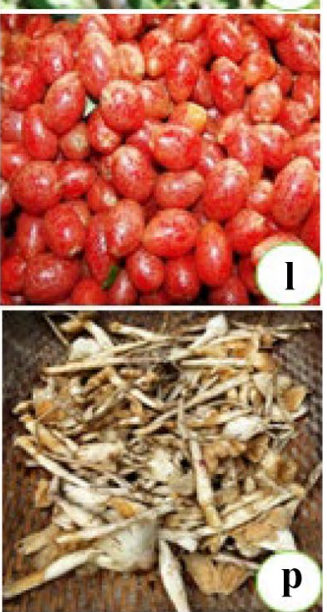

'glutinosa') is treasured for its aroma and normally used for making savoury snacks. Furthermore, the proportion of anti-nutritional factors such as phytic acidis much lower in all Meghalaya rice cultivars than that of most contemporary cultivars (Longvah et al., 2020). The substantial variation in iron content noted in the sticky rice genotypes commands of immense importance in the current prevalence of nutritional anaemia in a predominantly rice-consuming country. Butternut squash (Cucurbita moschata), a vegetable crop, is another example. It is recognized as a functional food around the world (Adams et al., 2011); the fruit is rich in vitamin $\mathrm{A}$ and was found in great abundance in a variety of fruit sizes, skin colours, and flesh colours in the study area and was put to multiple uses. The tender vine and flowers of pumpkin are also eaten as a vegetable. Yet another crop is Musa spp.; its pseudostem, flowers, and immature fruit are consumed as a vegetable and its ripe fruit is consumed as table fruit (Ghag \& Ganapathi, 2018). The local cuisines like 'Do.dim' (fermented soyabean) and 'Nakamsu.a' (fermented fish) are consumed by the Garo weekly, while the pseudostem of banana is an essential daily ingredient (Table 2). The high nutritional qualities of by-products of banana and the low cost of its production promote their use as a food resource with high nutrition and pharmaceutical values (Ramu et al., 2017).

About $92 \%$ of the households also raised chickens in the backyard. Wong et al. (2017) reported backyard poultry to be an accessible source of protein-rich food and of supplementary income for vulnerable households. Poultry, considered 'the gateway to national food security' (Gueye, 2009), fulfils many social and cultural functions in the area. For example, the early-morning calls of the males of the native species of poultry serve as a morning alarm, the birds are ritual sacrificial offerings to deities and ancestors, are given as gifts, and are eaten during feasts or on special occasions. Similarly, local people prefer the meat of indigenous pigs to that of commercial breeds despite the slow growth rate and low productivity of the indigenous breeds (Das, 2018). Also, these pigs possess important genetic traits such as high prolificacy, better feed conversion, early maturity, and greater resistance to seasonal parasites and diseases. These uses of livestock bond the indigenous people together and are part of their community life.

Accordingly, the local agrobiodiversity supports the Garo tribe with diverse and nutritious food from plants as well as domesticated animals. As an example of complexity, pigs 
Fig. 4 Products based on sticky rice: a. menilpita; b. menilrita; c. jakkep; d. sakkingata; e and f. traditional pots where 'chubitchi' is brewed; $\mathbf{g}$ and h. preparation of alkaline additive 'kalchi' from banana pseudostem. Meat-based preparations: i. wakkappa; j. Do.opura; k. Wakpura; l. Na. kambitchi; m. Na. tokwetepa (fish based); $\mathbf{n}$ to $\mathbf{p}$. traditional way of preparing 'na.kamsu.a' (fermented dry fish); q. we.tepa; r. O.sroma; s. dried flowers of Phlogacanthus thyrsiformis; $\mathbf{t}$. fermented bamboo shoots
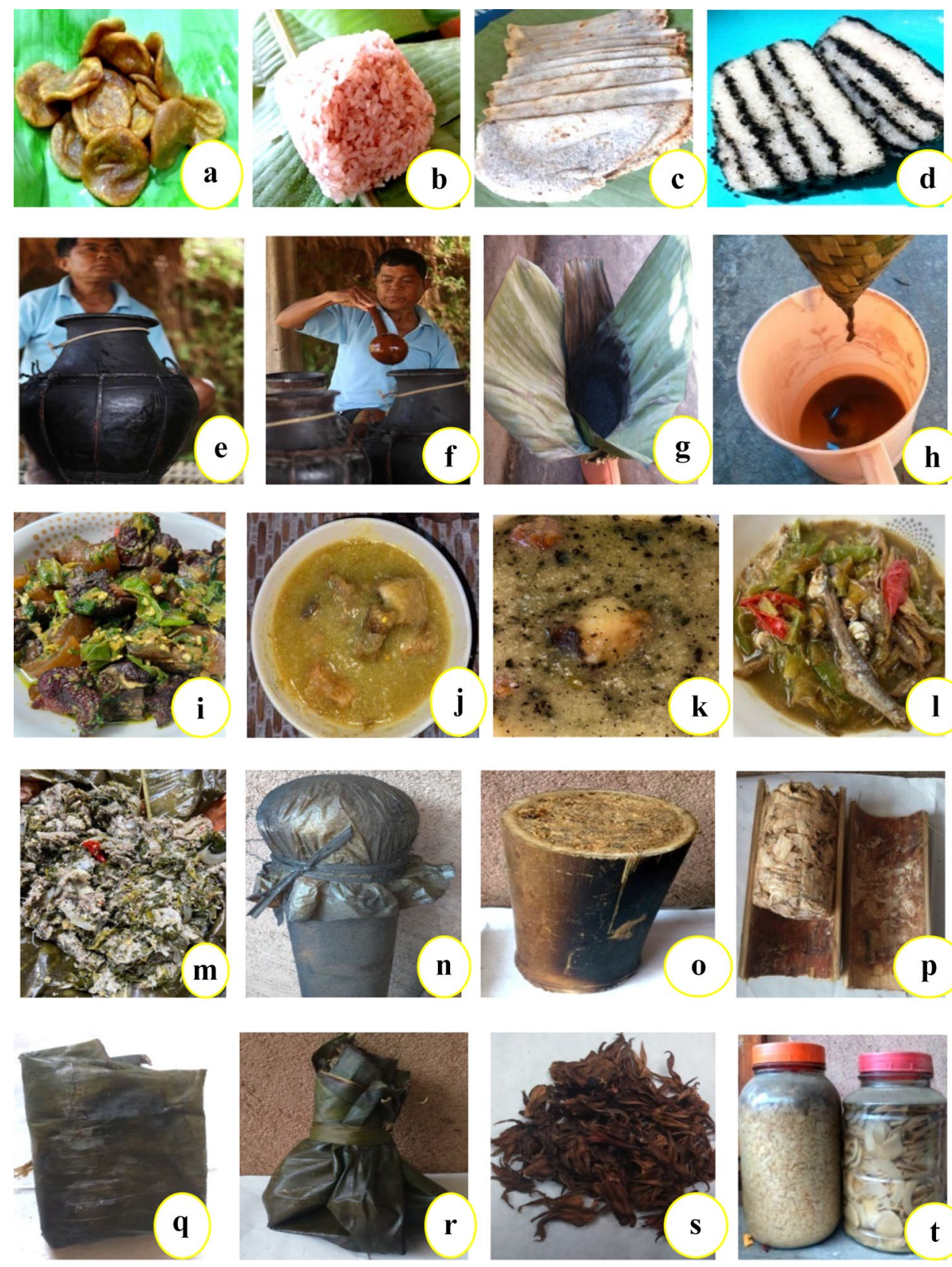

and poultry normally scavenge the area around a village during the day, and are given rice bran, maize, household waste products, wild tubers, and banana stems in the mornings and evenings. Livestock production and jhum are integrated through fodder production, the use of agricultural by-products as feed, and grazing in fallow lands. As part of Garo rituals, the harvest from jhum is offered first to local deities and their blessings are sought. For example, during 'gal maka'or 'a.gal', a male bird and rice beer are offered to seek the blessings of the Goddess Misi Saljong (the Goddess who first taught humankind the technique of cultivation) and during 'rongchugala' or 'gindegala' - a thanks giving -the first fruits are offered to her. The offering consists of freshly harvested, pounded, flattened, or powdered rice or millet grains served on a plantain leaf and sprinkled with rice beer. It was during the FGDs that we learnt about these rituals that signify the value of agrobiodiversity and food sovereignty in the socio-cultural life of the Garos. Food sovereignty emphasizes the fundamental recognition of indigenous peoples who nurture food systems that have been sustainable for thousands of years. Indigenous food sovereignty, thus, recognizes food as sacred and a crucial element of a web of relationships with the natural world for sustaining culture and community. Food, water, soil, and air are not merely the "resources" for them, but rather as the sources of life (Whyte, 2017). 
Table 3 Distribution of households based on diet diversity score (HDDS)

\begin{tabular}{|c|c|c|c|c|c|}
\hline \multicolumn{6}{|l|}{$\mathrm{n}=97$} \\
\hline \multirow[t]{3}{*}{ Item } & \multirow{2}{*}{\multicolumn{3}{|c|}{$\begin{array}{l}\text { Distribution of } \mathrm{HH} \text { based } \\
\text { HDDS (\%) }\end{array}$}} & \multirow{3}{*}{$\begin{array}{l}\text { Mean } \\
\text { HDDS } \\
\text { Score }\end{array}$} & \multirow{3}{*}{$\begin{array}{l}\text { Standard } \\
\text { Deviation } \\
\text { (HDDS } \\
\text { Score) }\end{array}$} \\
\hline & & & & & \\
\hline & $\begin{array}{l}\text { Low } \\
(<4.41)\end{array}$ & $\begin{array}{l}\text { Medium } \\
(4.41 \text { to } \\
7.23)\end{array}$ & $\begin{array}{l}\text { High } \\
(>7.23)\end{array}$ & & \\
\hline $\begin{array}{l}\text { HDDS } \\
\text { (12 food } \\
\text { groups) }\end{array}$ & $\begin{array}{l}22 \\
(22.68 \%)\end{array}$ & $\begin{array}{l}68 \\
(70.10 \%)\end{array}$ & $\begin{array}{l}7 \\
(7.22 \%)\end{array}$ & 5.82 & 1.41 \\
\hline
\end{tabular}

HDDS $=$ household dietary diversity score

With wild foods, fresh shoots of bamboo (Fig. 2) are the most commonly consumed food from the wild. This evidently denotes its sufficient availability and access by about 95\% households. Apart from its fresh use, dried and fermented bamboo shoots (Fig. 3t) are the stable supply round the year. Bamboo fits well in the traditional jhum system. It recovers well from forest fires (that are part of jhum farming) because the underground rhizome survives fires easily. In the short term, such fires benefit bamboo as the nutrient resources stored in the rhizome enable vigorous re-growth, out-competing other plants for space in the burned area (Barlow et al., 2012; Numata et al., 2017; Smith \& Nelson, 2011). Fresh or fermented bamboo shoots are indispensable to many local ethnic dishes and are low in calories, high in dietary fibre, and rich in various nutrients. Bamboo shoots are also rich in proteins, carbohydrates, amino acids, minerals, fat, sugar, fibre, and inorganic salts, especially potassium, calcium, manganese, zinc, chromium, copper, and iron and smaller amounts of phosphorus and selenium (Nirmala et al., 2007). Because of these qualities, bamboo shoots are considered to be a super food which is nutritious, healthy, and medicinal (Chongtham \& Bisht, 2020). Fewer households (less than $20 \%$ in each village) reported consuming wild edible fruits and vegetables, mushrooms, and medicinal plants, probably because such foods were either in short supply or not easily accessible to those households. A recent study reported that wild foods often contribute less to human diets in those areas under greater pressure from commercial agriculture or with more intense conservation efforts (Broegaard et al., 2017). However, accessing and using some of these wild resources also requires knowledge of the habitat of such species, their toxicity, and seasonal abundance; ignorance can prove hazardous and sometimes fatal (Pilgrim et al., 2008).

Our results establishes that food system biodiversity in the jhum landscape has strong link with dietary diversity (Table 3) among the Garo community. Our findings also get support from the recent study by Nongrum et al. (2021) who observed that women of Garo community are getting higher level of dietary diversity. In Meghalaya, there is a unique system of matrilineal and matriarchial system where women are custodians of the intergenerational property including even land. Thus, they are the pivot in preserving the rich biodiversity by conserving the seeds of traditional crops (Ellena \& Nongkynrih, 2017). However, the large-scale changes in land use in the jhum landscape of Garo Hills of Meghalaya have made cash crops the main focus of farming in the hills (GoM, 2019; NRSC, 2019). Such monoculture has changed the patterns of food consumption heralding a new food system and making both farmers and consumers vulnerable to vagaries of the market (Behera et al., 2016). Changes are most frequent in food grains, snacks, and drinks. The shift is being witnessed from home grown to purchased food and drink; from 'coarse' grain (such as the various millets, buckwheat, and amaranth) to 'fine' grain (white rice and white flour); and from traditional snacks and drinks to potato chips, instant noodles, and soft drinks (Rasul et al., 2017). These shifts in food preferences may have both long- and short-term implications for food security in the region.

Thus, strengthening the local food systems to reduce external dependencies and vulnerabilities ought to be the priority. This may be ensured by promoting traditional nutritious food crops which are also more resilient to climate induced stresses. Some interventions like community-based education for youth, and enhancing access to local seed resources through community seed banks needs institutional consideration. Moreover, retaining some proportion of the area under traditional land use shall be significant in accomplishing agricultural sustainability and improving nutrition quality in the region.

\section{Conclusions}

Our study assessed the agrobiodiversity and corresponding ethno-food diversity of an indigenous agroforestry system, jhum, practised in West Garo Hills in north-eastern India. The results show how agrobiodiversity in a traditional agroforestry system contributes to nutritional security by enriching dietary diversity. The contribution of this study lies in the documentation of ethnic foods of gastro-cultural and socio-ecological importance, which are derived mainly from local resources, both cultivated and those collected from the wild. This indigenous agroforestry system offers culturally appropriate foods for the local people and sustains their indigenous cultural food practices. This has immense potential for strengthening food security and is also important for food sovereignty. Such food systems have potential to bring appropriate grass roots changes in socioecological systems by developing bioregional economies, interconnections with customs and cultural events. Locally processed 
foods may be standardized and deployed in large-scale hunger eradicating programmes and those aimed at promoting better nutrition and livelihoods.

We suggest that traditional diets be modified to make them acceptable to younger members of households, while keeping in mind that such diets are intrinsic to the conservation of agrobiodiversity and have been shaped by the landscape and the livelihood dynamics of indigenous smallholders for generations. The study also warns against the ill effects of promoting monoculture in the pursuit of short-term gains, that threatens food security, dietary quality, and livelihood security of low-income households who are otherwise well protected because they practise jhum. Therefore, jhum needs support of renewed policy for its survival and modifying or improving it to make it more attractive and may address the food security needs of the Garo and related people in better manner.

Supplementary Information The online version contains supplementary material available at https://doi.org/10.1007/s12571-021-01251-y.

Acknowledgements We acknowledge the support obtained from Senior Scientist and Head, Krishi Vigyan Kendra, and the District Forest Officer of the West Garo Hills district, for their facilitation and monitoring during data collection. In addition, we sincerely acknowledge the participation of respondent jhumias and key informants during the survey work.

Funding This study was supported by the Agricultural Extension Division, Indian Council of Agricultural Research (ICAR), New Delhi, India. Grant Reference: File No. A.Extn.26/10/2015-AE-I/01.

Availability of data and materials All data and materials have been presented in the paper.

\section{Declarations}

Ethics approval This study was approved by the Directorate of Research, Central Agricultural University, Imphal, Manipur, India.

Consent to participate Prior informed consent was obtained from the Garo community before the study/FGDs.

Consent for publication Participants consented to the submission of the data to the journal.

Conflicts of interest The authors declare that they have no conflict of interest.

\section{References}

Adams, G. G., Imran, S., Wang, S., Mohammad, A., Kok, S., Gray, D. A., \& Harding, S. E. (2011). The hypoglycaemic effect of pumpkins as anti-diabetic and functional medicines. Food Research International, 44(4), 862-867. https://doi.org/10.1016/j.foodres. 2011.03.016

Barlow, J., Silveira, J. M., Mestre, L. A., Andrade, R. B., D'Andrea, G. C., Louzada, J., Vaz-de-Mello, F. Z., Numata, I., Lacau, S. \& Cochrane, M.A. (2012). Wildfires in bamboo-dominated
Amazonian forest: impacts on above-ground biomass and biodiversity. PloS One, 7(3), p.e33373.https://doi.org/10.1371/ journal.pone. 0033373

Behera, P., \& Balaji, S. (2021). Health benefits of fermented bamboo shoots: The twenty-first century green gold of Northeast India. Applied Biochemistry and Biotechnology, 193, 1800-1812. https://doi.org/10.1007/s12010-021-03506-y

Behera, R. N., Nayak, D. K., Andersen, P., \& Måren, I. E. (2016). From jhum to broom: Agricultural land-use change and food security implications on the Meghalaya Plateau. India. Ambio, 45(1), 63-77. https://doi.org/10.1007/s13280-015-0691-3

Berners-Lee, M., Kennelly, C., Watson, R., Hewitt, C. N., Kapuscinski, A. R., Locke, K. A. et al., \& Peters, C. J. (2018). Current global food production is sufficient to meet human nutritional needs in 2050 provided there is radical societal adaptation. Elementa: Science of the Anthropocene, 6. https://doi.org/10.1525/elementa.310

Broegaard, R. B., Rasmussen, L. V., Dawson, N., Mertz, O., Vongvisouk, T., \& Grogan, K. (2017). Wild food collection and nutrition under commercial agriculture expansion in agriculture-forest landscapes. Forest Policy and Economics, 84, 92-101. https://doi.org/10.1016/j. forpol.2016.12.012

Chappell, M. J., \& LaValle, L. A. (2011). Food security and biodiversity: can we have both? An agroecological analysis. Agriculture and Human Values, 28(1), 3-26.https://doi.org/10.1007/ s10460-009-9251-4

Chongtham, N., \& Bisht, M. S. (2020). Bamboo Shoot: Superfood for Nutrition. CRC Press.

Das T., \& Das A. K. (2020). Agrobiodiversity in Northeast India: A Review of the Prospects of Agrobiodiversity Management in the Traditional Rice Fields and Homegardens of the Region. In: Roy N., Roychoudhury S., Nautiyal S., Agarwal S., Baksi S. (eds) Socio-economic and Eco-biological Dimensions in Resource use and Conservation. Environmental Science and Engineering. Springer, Cham. https://doi.org/10.1007/978-3-030-32463-6_6.

Das, D. (2018). Arunachal Pradesh Pig Breeding Policy. Department of Animal Husbandry, Veterinary \& Dairy Development, Itanagar, No. 94, Vol. XXVI, Naharlagun. Government of Arunachal Pradesh. 2018. Retrieved from https://www.arunachalpradesh.gov. in/wp-content/uploads/extraordinary_gazette/1561535852_94.\% 20E.O.\%20Gazette\%20No.\%2094\%20(2019)\%20(AHVDD).pdf.

Deb, S. (2020). Traditional Agroforestry Systems of Northeast India. Socio-economic and Eco-biological Dimensions in Resource use and Conservation (pp. 103-115). Springer.

Dupuis, J. A., \& Goulard, M. (2011). Estimating species richness from quadrat sampling data: A general approach. Biometrics, 67(4), 1489-1497. https://doi.org/10.1111/j.1541-0420.2011.01595.x

Ellena, R., \& Nongkynrih, K. A. (2017). Changing gender roles and relations in food provisioning among matrilineal Khasi and patrilineal Chakhesang Indigenous rural People of North-East India. Maternal \& child nutrition, 13, e12560.

Fanzo, J., Holmes, M., Junega, P., Musinguzi, E., Smith, I. F., Ekesa, B., \& Bergamini, N. (2011). Improving nutrition with agricultural biodiversity.Bioversity International, n. 78 p.

FAOSTAT. (2018). Retrieved fromhttp://www.fao.org/faostat/en/\#data.

Freitas, H., Oliveira, M., Jenkins, M., \& Popjoy, O. (1998). The Focus Group, a qualitative research method. Journal of Education, 1(1), $1-22$.

FSI. (2019). India state of forest report 2019. Forest Survey of India, Ministry of Environment, Forest and Climate Change. Government of India, Dehradun.

Guo, H., Padoch, C., Fu, Y., Dao, Z., \& Coffey, K. (2002). Household level agrobiodiversity assessment. Cultivating biodiversityunderstanding, analysing and using agricultural diversity. London: ITDG Publishing. p, 70-77.

Ghag, S. B., \& Ganapathi, T. R. (2018). Banana and Plantains: Improvement. Nutrition, and Health. In: MÉRILLON JM, 
RAMAWAT K.(Eds) Bioactive Molecules in Food. Reference Series in Phytochemistry. Springer, Cham, 1, 1-20.

Giri, K., Mishra, G., Rawat, M., Pandey, S., Bhattacharyya, R., Bora, N., \& Rai, J. P. N. (2020). Traditional Farming Systems and Agro-biodiversity in Eastern Himalayan Region of India. In: Goel R., Soni R., Suyal D. (eds) Microbiological Advancements for Higher Altitude Agro-Ecosystems \& Sustainability. Rhizosphere Biology. Springer, Singapore. https://doi.org/10.1007/ 978-981-15-1902-4_5

GoM. (2021). Government of Meghalaya, South West Garo Hills District, People and their culture. Retrieved from http://southwestgarohills. gov.in/peopleculture.html.

GoM. (2019). Statistical Handbook. Directorate of economics and statistics, 2019; Government of Meghalaya, Shillong.

Government of India. (2011). Census of INDIA. Office of the Registrar General, 2011; India.

Gueye, E. F. (2009). The role of networks in information dissemination to family poultry farmers. World's Poultry Science Journal, 65(1), 115-124.https://doi.org/10.1017/S0043933909000099

Herforth, A., Arimond, M., Álvarez-Sánchez, C., Coates, J., Christianson, K., \& Muehlhoff, E. (2019). A global review of food-based dietary guidelines. Advances in Nutrition, 10(4), 590-605. https://doi.org/ 10.1093/advances/nmy130

Hunter, D., \& Fanzo, J. (2013). Introduction: Agricultural biodiversity, diverse diets and improving nutrition. In Diversifying Food and Diets (pp. 33-46). Routledge.

Ickowitz, A., Rowland, D., Powell, B., Salim, M. A., \& Sunderland, T. (2016). Forests, trees, and micronutrient-rich food consumption in Indonesia. PloS One, 11(5), e0154139.https://doi.org/10.1371/ journal.pone. 0154139

Jeeva, S. R. D. N., Laloo, R. C., \& Mishra, B. P. (2006). Traditional agricultural practices in Meghalaya, North East India. Indian Journal of Traditional Knowledge, 5(1), 7-18.

Johns, T., \& Eyzaguirre, P. B. (2006). Linking biodiversity, diet and health in policy and practice. Proceedings of the Nutrition Society, 65(2), 182-189. https://doi.org/10.1079/PNS2006494

Johns, T., \& Sthapit, B. R. (2004). Biocultural diversity in the sustainability of developing-country food systems. Food and Nutrition Bulletin, 25(2), 143-155.https://doi.org/10.1177/ 156482650402500207

Jones, A. D. (2017). Critical review of the emerging research evidence on agricultural biodiversity, diet diversity, and nutritional status in low-and middle-income countries. Nutrition Reviews, 75(10), 769-782.https://doi.org/10.1093/nutrit/nux040

Kennedy, G., Ballard, T., \& Dop, M. C. (2010). Guidelines for measuring household and individual dietary diversity. Food and Agriculture Organization of the United Nations.

Khoury, C. K., Bjorkman, A. D., Dempewolf, H., Ramirez-Villegas, J., Guarino, L., Jarvis, A., Rieseberg, L. H., \& Struik, P. C. (2014). Increasing homogeneity in global food supplies and the implications for food security. Proceedings of the National Academy of Sciences, 111(11), 4001-4006.https://doi.org/10.1073/pnas. 1313490111

Kuhnlein H. V., Erasmus B., \& Spigelski, D. (2009). Indigenous Peoples' Food Systems: The Many Dimensions of Culture, Diversity and Environment for Nutrition and Health; Food and Agriculture Organization of the United Nations: Rome, Italy.

Kuhnlein, H. V. (2017). Human nutrition and health of Indigenous Peoples. Routledge Handbook of Agricultural Biodiversity, 388. Routledge. London, UK.

Kuhnlein, H. V., Erasmus, B., Spigelski, D., \& Burlingame, B. (2013). Indigenous peoples' food systems and well-being: interventions and policies for healthy communities. Food and agriculture Organization of the United Nations (FAO).

Kuhnlein, H. V., Smitasiri, S., Yesudas, S., Bhattacharjee, L., Dan, L., \& Ahmed, S. (2006). Documenting traditional food systems of indigenous peoples: international case studies. Centre for Indigenous Peoples' Nutrition and Environment, McGill University, Sainte-Anne-de-Bellevue, Quebec. Retrieved from www. mcgill. $\mathrm{ca} /$ files/cine/manual. pdf.

Kurien, A. J., Lele, S., \& Nagendra, H. (2019). Farms or Forests? Understanding and mapping shifting cultivation using the case study of West Garo hills, India. Land, 8(9), 133.https://doi.org/ 10.3390/land8090133

Lahiri, B., \& Das, P. (2010). Role of nokma (village headman) in agriculture of West Garo Hills. Meghalaya. Journal of Extension Education, 25(1 \& 2), 72-82.

Longvah, T., Sai, P. V. S., Rajendran, A., Kharkhonger, G. C., \& Rangad, C. (2020). In situ nutrient variability in rice landraces from Garo Hills, Meghalaya in North East India. Journal of Food Composition and Analysis, 92, 103543.https://doi.org/10.1016/j.jfca.2020. 103543

Lourme-Ruiz, A., Dury, S., \& Martin-Prével, Y. (2021). Linkages between dietary diversity and indicators of agricultural biodiversity in Burkina Faso. Food Security, 13(2), 329-349.https://doi. org/10.1007/s 12571-020-01137-5

Maaker, E. D. (2013). Performing the Garo nation? Garo Wangala dancing between faith and folklore. Asian Ethnology, 72(2), 221-239.

Marak, Q. (2018). Rice from A• ba: Stories, rituals and practices of the Garos. South Asian Anthropologist, 18(2), 161-175.

Materia, V. C., Linnemann, A. R., Smid, E. J., \& Schoustra, S. E. (2021). Contribution of traditional fermented foods to food systems transformation: value addition and inclusive entrepreneurship. Food Security, 13(5),1163-1177.https://doi.org/10.1007/ s12571-021-01185-5

Morgan, D. L. (1988). Focus group as qualitative research. Sage Publications Inc.

Murray, J. M., \& Baxter, I. A. (2003). I SENSORY EVALUATION I Food acceptability and sensory evaluation. In B. Caballero (Ed.), Encyclopedia of Food Sciences and Nutrition (pp. 5130e5136). Oxford, UK: Academic Press.

National Institute of Nutrition. (2011). Manual, A Dietary Guideline for Indians. 2011; 2, 89-117.

Nemoga, G. (2019). Indigenous agrobiodiversity and governance. Agrobiodiversity: Integrating Knowledge for a Sustainable Future, 241-264. MIT Press.

Nirmala, C., David, E., \& Sharma, M. L. (2007). Changes in nutrient components during ageing of emerging juvenile bamboo shoots. International Journal of Food Sciences and Nutrition, 58(8), 612-618.https://doi.org/10.1080/09637480701359529

Nongkynrih, D. (2014). Land relations in the tribal societies of Meghalaya: Changing patterns of land use and ownership. Social Change and Development, 11(2), 1-20.

Nongrum, M. S., Pawera, L., \& Mawroh, B. (2021). Dietary diversity and its determinants among Khasi and Garo indigenous women (15 to 49 years) in Meghalaya, northeast India. Nutrition and Health, 0 2601060211016629. https://doi.org/10.1177/02601060211016629

NRSC. (2019). Wasteland Atlas of India-, National Remote Sensing Centre (NRSC), Department of Space. 2019. Retrieved from https://dolr.gov.in/documents/wasteland-atlas-of-india.

Numata, I., Silva, S. S., Cochrane, M. A., \& d'Oliveira, M. V. (2017). Fire and edge effects in a fragmented tropical forest landscape in the southwestern Amazon. Forest Ecology and Management, 401, 135-146.https://doi.org/10.1016/j.foreco.2017.07.010

Pachuau L.\&Dutta R.S. (2020). Wild Edible Fruits of Northeast India: Medicinal Values and Traditional Practices. In: Sen S., Chakraborty R. (eds) Herbal Medicine in India. Springer, Singapore. https://doi.org/10.1007/978-981-13-7248-3_27.

Padulosi, S., Thompson, J., \& Rudebjer, P. G. (2013). Fighting poverty, hunger and malnutrition with neglected and underutilized species: needs, challenges and the way forward.Retrieved from https://cgspace.cgiar.org/handle/10568/68927. 
PAR. (2018). Assessing Agrobiodiversity: A Compendium of Methods; Mijatovi'c, D., Hodgkin, T., Eds.; Platform for Agrobiodiversity Research, 2018; Rome, Italy.

Pilgrim, S. E., Cullen, L. C., Smith, D. J., \& Pretty, J. (2008). Ecological knowledge is lost in wealthier communities and countries.Environmental Science \& Technology, 42(4), 10041009.https://doi.org/10.1021/es070837v

Pilling, D., Bélanger, J., \& Hoffmann, I. (2020). Declining biodiversity for food and agriculture needs urgent global action. Nature Food, 1(3), 144-147. https://doi.org/10.1038/s43016-020-0040-y

Poore, J., \& Nemecek, T. (2018). Reducing food's environmental impacts through producers and consumers. Science, 360(6392), 987-992. https://doi.org/10.1126/science.aaq0216

Ramu, R., Shirahatti, P. S., Anilakumar, K. R., Nayakavadi, S., Zameer, F., Dhananjaya, B. L., \& Prasad, M. N. (2017). Assessment of nutritional quality and global antioxidant response of banana (Musa sp. CV. Nanjangud Rasa Bale) pseudostem and flower. Pharmacognosy Research, 9(Suppl1), S74. https://doi.org/10. 4103/pr.pr_67_17

Rasul, G., Hussain, A., Mahapatra, B., \& Dangol, N. (2017). Food and nutrition security in the Hindu Kush Himalayan region. Journal of the Science of Food and Agriculture, 98(2), 429-438. https:// doi.org/10.1002/jsfa. 8530

Rathore, S. S., Karunakaran, K., \& Prakash, B. (2010). Alder based farming system a traditional farming practices in Nagaland for amelioration of jhum land. Indian Journal of Traditional Knowledge, 9(4), 677-680.

Reddy, G., \& van Dam, R. M. (2020). Food, culture, and identity in multicultural societies: Insights from Singapore. Appetite, 149, 104633.https://doi.org/10.1016/j.appet.2020.104633

Ruel, M. T. (2003). Operationalizing dietary diversity: a review of measurement issues and research priorities. The Journal of Nutrition, 133(11), 3911S-3926S.https://doi.org/10.1093/jn/133.11. $3911 \mathrm{~S}$

Sangma, M. S. (2012). History and Culture of the Garos. North East Printing Press.

Smith, M., \& Nelson, B. W. (2011). Fire favours expansion of bamboodominated forests in the south-west Amazon. Journal of Tropical Ecology, 27(1), 59-64. https://doi.org/10.1017/S026646741000057X

Vogliano, C., Raneri, J. E., Coad, J., Tutua, S., Wham, C., Lachat, C., \& Burlingame, B. (2021). Dietary agrobiodiversity for improved nutrition and health outcomes within a transitioning indigenous Solomon Island food system. Food Security, 13(4), 819-847. https://doi.org/10.1007/s12571-021-01167-7

Whyte, K. P. (2017). Food Sovereignty, Justice and Indigenous Peoples: An Essay on Settler Colonialism and Collective Continuance. Oxford Handbook on Food Ethics. Edited by A. Barnhill, T. Doggett, and A. Egan. Oxford University Press.

Wong, J. T., de Bruyn, J., Bagnol, B., Grieve, H., Li, M., Pym, R., \& Alders, R. G. (2017). Small-scale poultry and food security in resource-poor settings: A review. Global Food Security, 15, 43-52.https://doi.org/10.1016/j.gfs.2017.04.003

Zimmerer, K. S., \& De Haan, S. (2017). Agrobiodiversity and a sustainable food future. Nature Plants, 3(4), 1-3. https://doi.org/10. 1038/nplants.2017.47

Zimmerer, K. S., \& de Haan, S. (2020). Informal food chains and agrobiodiversity need strengthening - not weakening-to address food security amidst the COVID-19 crisis in South America. Food Security, 12(4), 891-894.https://doi.org/10.1007/ s12571-020-01088-x

Zimmerer, K. S., de Haan, S., Jones, A. D., Creed-Kanashiro, H., Tello, M., Carrasco, M., et al. (2019). The biodiversity of food and agriculture (Agrobiodiversity) in the anthropocene:
Research advances and conceptual framework. Anthropocene, 25, 100192.https://doi.org/10.1016/j.ancene.2019.100192

Zimmerer, K. S., De Haan, S., Jones, A. D., Creed-Kanashiro, H., Tello, M., Amaya, F. P., et al. (2020). Indigenous smallholder struggles in Peru: Nutrition security, agrobiodiversity, and food sovereignty amid transforming global systems and climate change. Journal of Latin American Geography, 19(3), 74-111.https://doi.org/10.1353/lag.2020.0072.

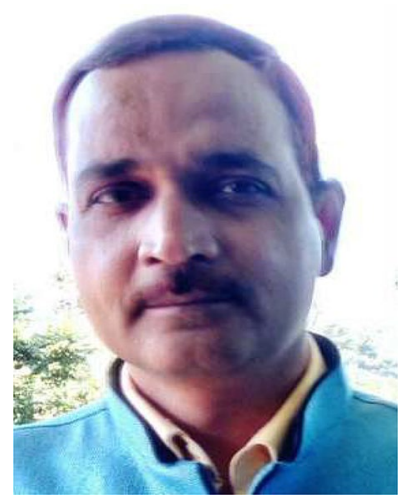

Dileep Kumar Pandey Ph D Is an Associate Professor, Extension Education at College of Horticulture \& Forestry, Central Agricultural University (Manipur), Pasighat-791102. Apart from undergraduate and postgraduate teaching and technology transfer, Dr Pandey is actively engaged in research. As a Principal Investigator, he successfully completed two research projects, namely (1) Mapping of Socio-economic and Livelihood Patterns of Jhumias in North East Hill Region of India and (2) Impact of Information and Communication Technologies in Agricultural Education in India, funded by Indian Council of Agricultural Research, New Delhi. Currently, Dr Pandey is working on agrobiodiversity and ecosystem services and diversity in indigenous foods and well-being. His notable contribution was to examine the continuance of shifting cultivation using the concept of place attachment (recently published in Forest Policy and Economics, a leading international peer-reviewed journal. As a lead author, Dr Pandey has more than 30 scientific articles, 5 of which were published in Current Science, century-old journal published by the Current Science Association, Bengaluru, India.

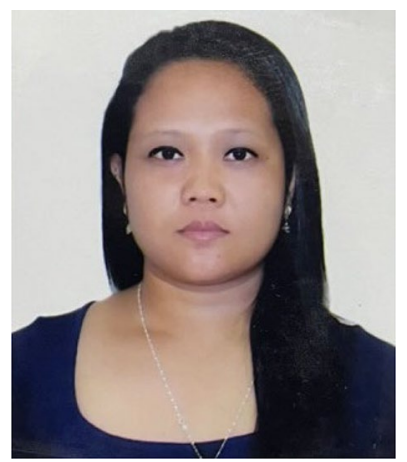

Kalkame Cheran Momin, $\mathrm{Ph}$ D (Floriculture and Landscaping)is an Assistant Professor at College of Horticulture \& Forestry, Central Agricultural University (Manipur), Pasighat791102. Arunachal Pradesh, India. She is working on Ethnobotanical study of wild plants in Garo Hills region of Meghalaya and their usage, wild edible fruits and promising spices of North East India, native ornamental plants and dried flowers. She is a recipient of Dr. Panjabrao Deshmukh Birth Centenary Gold Medal, Barrister Sheshrao Wankhade Gold Medal, Shri Madhao Gangadhar Bhumralkar Cash Prize, Annasaheb Mahajani Cash Prize for being the university topper in M. Sc. Agri. (Horti) in the year 2009 conferred by Dr Panjabrao Deshmukh Krishi Vidyapeeth, Akola, Maharashtra, India. She has been awarded INSPIRE fellowship by Department of Biotechnology, Govt. of India during her Ph. D programme. Dr. Momin has over 15 research publications, 4 books and 16 book chapters. She is handling one externally funded project as Principal Investigator and 3 projects as Co-Principal Investigator. 


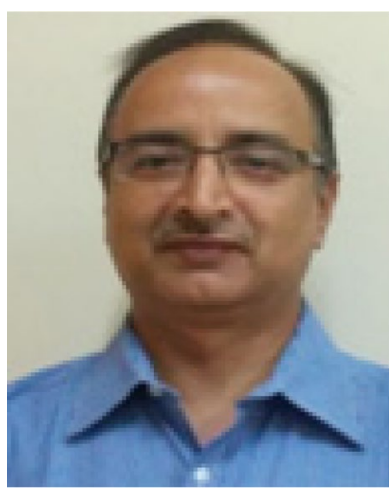

ShantanuKumar Dubey Working as the Principal Scientist (Agricultural Extension), Indian Council of Agricultural Research - AgriculturalTechnology Application Research Institute, Kanpur, India. He has evolved the empirical paradigms for technology integration and gender empowerment for tribals of North East region of India, experimented on participatory seed production through farmers institution building, validated postal agriextension systems, stratified the Indian states on axis of yield gap \& potentialyield of major crops and developed the stakeholders grid. Worked on Model Village and Institute-voluntary organization linkage concept for technology dissemination. Dr Dubey has implemented 16 in-house and 13 externally funded research projects. He has won several awards and has 103 research papers, 10 books, 13 bulletins and other related publications to his credit.

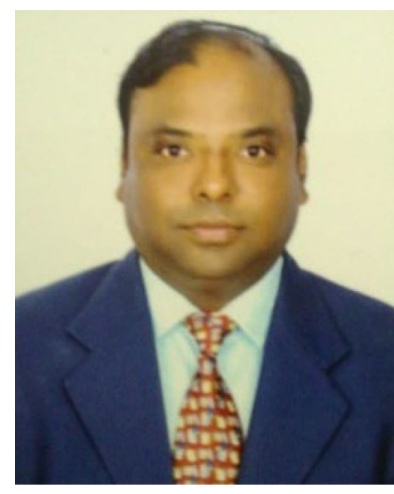

PoovaragavaluAdhiguru Working as Principal Scientist (Agricultural Extension) at Indian Council of Agricultural Research Head Quarter, New Delhi, India. His significant research project experience includes coordinating 39 Indian Council of Agricultural Research -extramural research projects in extension. Also, handled projects like Agricultural Science and Technology Indicators" [Indian Council of Agricultural Research -IFPRI], Sustainable rainfed agriculture- impact assessment of World Bank sponsored Watersheds Indian Council of Agricultural Research -IFPRI-ICRISAT-ODI-CRIDA-World Bank], also, nodal officer for CSISA project of CIMMYT. The other projects include Attracting and Retaining Youth in Agriculture dealing with agripreneurship, ICT-mediated Agricultural Extension, Geometry of information flow in agriculture, Agricultural-based interventions for sustainable nutritional security. 